\title{
FOREWORD
}

\section{The Varieties of Constitutional Change}

\author{
LAWRENCE FRIEDMAN*
}

S Oliver Wendell Holmes observed nearly a century ago, the
U.S. Constitution's framers "called into life a being the
development of which could not have been foreseen completely by the most gifted of its begetters." 1 And while federal constitutional law has changed over the two hundred plus years since the framing, relatively little of that development was the result of the formal amendment process prescribed by Article V. Rather, significantly more change to our understanding of numerous constitutional provisions has come about through litigation over the meaning of the text. ${ }^{2}$ Regardless of the source of constitutional alteration, we regard the result as valid constitutional law. But that difference in source has fueled a great many efforts to legitimize judicial interpretation as a mode of constitutional change-to legitimize, that is, constitutional development by the least representative, least accountable department of the federal government.

State constitutions, as they do in other respects, tell a different story. ${ }^{3}$

* Professor of Law, New England Law I Boston.

1 Missouri v. Holland, 252 U.S. 416, 433 (1920). Sanford Levinson has noted the respect for Holmes's conclusion shown by judges who differ widely in their approaches to constitutional interpretation. See SANFORD LEVINSON, How Many Times Has the United States Constitution Been Amended? (A) <26; (B) 26; (C) 27; (D) > 27: Accounting for Constitutional Change, in RESPONDING

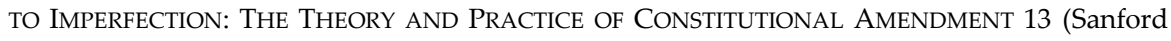
Levinson, ed. 1995).

2 See David A. Strauss, The Irrelevance of Constitutional Amendments, 114 HARV. L. REV. 1457, 1459 (2001) (discussing the role of judicial review in bringing about federal constitutional change). James Gardner has also elaborated on practice-driven constitutional change. See James A. Gardner, Practice-Driven Changes to Constitutional Structures of Governance, 69 ARK. L. REV. 335 (2016).

3 See, e.g., EMILY, ZACKIN, LOOKING For Rights IN ALL THE WrONG Places: Why STATE CONSTITUTIONS CONTAIN AMERICA's POSITIVE Rights (2013) (discussing, in contrast to the federal constitution's protection of negative rights, the numerous provisions in state 
In the state constitutional context, the tension between litigation-driven change and amendment-driven change is diminished by the fact that formal amendment is a more realistic proposition that it is under the U.S. Constitution. As Professor Jonathan Marshfield notes in the article that serves as the centerpiece of this symposium, "Courts and Informal Constitutional Change in the States," "[w] hen compared to the Federal Constitution, which has been amended only 27 times since 1789, state constitutions are a 'beehive' of amendment activity. Indeed, state constitutions rank among the most frequently amended constitutions in the world." 4

Understanding state constitutional change is important, Marshfield reminds us, because of the central role state regulation plays in nearly all aspects of the lives of Americans. ${ }^{5}$ State officials direct policy decisions "regarding education, health and safety, transportation, criminal justice, private trade and contracts, land use, the environment, and many other things." 6 Given that so many aspects of our lives fall within the reach of state regulation, there is a practical need for "reliable information about how state constitutions evolve and change." 7 To that end, "Courts and Informal Constitutional Change in the States" may be seen as a response to the prevailing view, which holds that, "when formal amendment is frequent and relatively easy, informal amendment is presumed to be nominal because pressures for constitutional change are adequately addressed through formal amendment." 8

To explore the influence of informal constitutional change in the states, Marshfield relies upon an original database of state supreme courts decisions from across the nation, focusing on the instances in which those courts "brought about a change in binding constitutional doctrine by explicitly and independently overruling a prior constitutional precedent." 9 The results of this inquiry reveal that, notwithstanding the availability of formal amendment mechanisms, state high courts regularly interpret their state charters in ways that result in constitutional change, particularly in the area of individual rights. ${ }^{10}$ This conclusion raises questions about the

constitutions protecting positive rights).

4 Jonathan L. Marshfield, Courts and Informal Constitutional Change in the States, 52 NEW ENG. L. ReV. 453, 456 (2017). This piece builds upon Marshfield's prior empirical work, in particular The Amendment Effect, 98 BOSTON U. L. REV. 55 (2018).

${ }^{5} \mathrm{Id}$. at $455-56$.

6 Id. at 455.

7 Id.

8 Id at 457.

${ }^{9}$ Id at 458-59.

10 See Marshfield, supra note 4, at 459-60. 
nature of constitutional change at the state level. Why, for instance, despite the lower barriers to formal amendment, have state courts remain actively engaged in effecting change? Marshfield speculates that, perhaps, American political culture prefers the resolution of certain issues, like the scope of individual rights, through the judicial process. ${ }^{11}$ Or, perhaps the relative indeterminacy of rights provisions simply compels more frequent judicial attention. ${ }^{12}$ As he acknowledges, the answers to these questions await further inquiry.

The contributors to this symposium see a variety of possibilities in Marshfield's data and analysis. In his contribution to this symposium, "The Difficulty of Mathematically Measuring the Many Factors Driving Constitutional Change in Our State Supreme Courts: A Judicial Perspective,"13 Scott Kafker, an associate justice of the Massachusetts Supreme Judicial Court, brings a different perspective to Marshfield's work. He approaches the subject of state constitutional change as an insider, noting the range of jurisprudential and structural factors that might account for constitutional change in a particular instance, whether the change is formal or informal. ${ }^{14} \mathrm{He}$ also examines the considerations a judge might have in mind when faced with competing arguments about the necessity of constitutional change, as well as the light Marshfield's work sheds on the relationship between the different kinds of change. ${ }^{15}$

Justin Long, in his essay, "State Constitutions Are Slippery: A Reply to Professor Marshfield," 16 questions why, as Marshfield's data demonstrate, the rates of both formal and informal constitutional change in the states is high. He does so by approaching the issue of constitutional change from an economic perspective, by examining the risks and rewards of the differing paths to change at both the federal and state levels. ${ }^{17}$ His inquiry suggests that the products of the changes wrought by amendment and litigation, respectively, may be substantively and expressively different-which tells us something about why proponents of particular change might choose to pursue one path over the other. ${ }^{18}$ Like his fellow contributors, Long

\footnotetext{
11 See id. at 460.

12 See id.

13 Scott Kafker, The Difficulty of Mathematically Measuring the Many Factors Driving Constitutional Change in Our State Supreme Courts: A Judicial Perspective, 51 NeW ENG. L. Rev. 517 (2017)

14 See id. at 517-19.

15 Id. at 524-28.

16 Justin R. Long, State Constitutions Are Slippery: A Reply to Professor Marshfield, 52 NEW ENG. L. REV. 531 (2017).

17 See id. at 536-37.

18 Id. at 533-34.
} 
welcomes Marshfield's "careful documentation of the nature of these changes and his invitation to reconsider the constitutional verities that animate federal constitutionalism." 19

For his part, James Gardner, in his contribution, "Active Judicial Governance," 20 argues that Marshfield's study "provides convincing evidence of an important fact: state high court judges participate actively and routinely in the processes of public governance, and they do so more openly and, apparently, with greater comfort and confidence than their federal counterparts." 21 In other words, Marshfield's work lends support to the position that many state court judges conceive of the judicial role as within a system of government designed primarily to promote the public good, and not, as many modern U.S. Supreme Court justices have suggested of the federal judicial role, as standing apart from the dynamic processes of democratic governance. ${ }^{22}$

Finally, Yaniv Roznai, in his essay, "Unconstitutional Constitutional Change by Courts," 23 uses Marshfield's work as an opportunity to examine, in a preliminary way, the competence of the courts "to bring about a constitutional change." $24 \mathrm{He}$ begins from the premise that state constitutions, like many national constitutions, contain certain "subjects, principles, rules and institutions [that] are beyond the ordinary amendment power," which means state courts also may be "limited in their scope of generating informal constitutional amendments through judicial interpretation." 25 As Roznai notes, state constitutions contain a basic structure that limits not only amending actors, but judges as well. ${ }^{26} \mathrm{It}$ follows that certain informal state constitutional changes may in fact be unconstitutional-a possibility that itself warrants fuller exploration. ${ }^{27}$

In the end, "Courts and Informal Constitutional Change in the States" serves as a jumping-off point for further investigation into the nature of, and reasons for, constitutional change. As Robert Williams observes in his essay, "New Light on State Constitutional Change," "[t]here is much more to be learned about our state constitutional tradition. In fact, maybe we

19 Id. at 540 .

20 James A. Gardner, Active Judicial Governance, 51 NEW ENG. L. ReV. 545 (2017).

$21 \mathrm{Id}$. at 548 .

22 See id. at 549-50.

23 Yaniv Roznai, Unconstitutional Constitutional Change by Courts, 51 NEW ENG. L. REV. 555 (2017).

24 Id. at 556.

25 Id. at 567.

26 See id. at 564 .

27 See id. at 569-70. 
have only begun to scratch the surface of the field." ${ }^{28}$ It is a point on which I suspect we would find general agreement among the contributors to this symposium, as well as those commentators and jurists whose work addresses the sub-national constitutional experience.

28 Robert Williams, New Light on State Constitutional Change, 51 NEW. ENG. L. REV. 541, 544 (2017). 